\title{
Peningkatan Hasil Belajar Menggunakan Model Problem Based Learning (PBL) pada Peserta Didik Kelas V SD Negeri 2 Tlahab Lor
}

\section{Triyati}

SD Negeri 2 Tlahab Lor

tritriyati91@gmail.com

\section{Article History}

received 3/12/2020

\begin{abstract}
This study aims to improve the learning outcomes of fifth grade students of SD NEGERI 2 TLAHAB LOR in integrated thematic learning theme 9 using the Problem Based Learning (PBL) learning model. Integrated thematic learning is learning that uses theme in learning activities by combining several lesson content in each lesson. The hope of integrated thematic learning is that students can gain hands-on experience to be able to find their own various knowledge learned. So that learning is more meaningful. This research is a classroom action research conducted in two cycles. The research subjects were 26 students of class V. Data collection techniques used observation and learning outcomes tests. The results showed that the learning outcomes of the pre-action obtained the percentage of completeness $23.08 \%$ or 6 students who met the KKM with an average value of 47.16. In the first cycle of learning outcomes, the percentage of completeness was $34.62 \%$ or 9 students who met the KKM with an average score of 55.26. Cycle II learning outcomes obtained the percentage of completeness $57.69 \%$ or 15 students who meet the KKM with an average value of 66.88 .
\end{abstract}

Keywords: problem based learning, integrated thematic learning, learning outcomes

\begin{abstract}
Abstrak
Penelitian ini bertujuan untuk peningkatan hasil belajar peserta didik kelas $V$ SD NEGERI 2 TLAHAB LOR dalam pembelajaran tematik terpadu tema 9 menggunakan model pembelajaran Problem Based Learning (PBL). Pembelajaran tematik terpadu adalah pembelajaran yang menggunakan tema dalam kegiatan pembelajaran dengan memadukan beberapa muatan pelajaran dalam setiap pembelajaran. Harapan dari pembelajaran tematik terpadu adalah peserta didik dapat memperoleh pengalaman secara langsung untuk dapat menemukan sendiri berbagai pengetahuan yang dipelajari. Sehingga pembelajaran lebih bermakna.Penelitian ini adalah penelitian tindakan kelas yang dilaksanakan sebanyak dua siklus. Subjek penelitian adalah 26 peserta didik kelas $\mathrm{V}$. Teknik pengumpulan data menggunakan observasi dan tes hasil belajar. Hasil penelitian menunjukkan bahwa hasil belajar dari pra tindakan diperoleh persentase ketuntasan $23,08 \%$ atau 6 siswa yang memenuhi KKM dengan nilai rata-rata 47,16. Siklus I hasil belajar diperoleh persentase ketuntasan $34.62 \%$ atau 9 siswa yang memenuhi KKM dengan nilai rata-rata 55,26 . Siklus II hasil belajar diperoleh persentase ketuntasan $57,69 \%$ atau 15 siswa yang memenuhi KKM dengan nilai rata-rata 66,88.
\end{abstract}

Kata kunci: problem based learning, pembelajaran tematik terpadu, hasil belajar

Social, Humanities, and Education Studies (SHEs): Conference Series https://jurnal.uns.ac.id/shes

p-ISSN 2620-9284

e-ISSN 2620-9292 


\section{PENDAHULUAN}

Pembelajaran yang diterapkan di Sekolah Dasar berdasarkan kurikulum 2013 adalah adalah pembelajaran tematik terpadu. Pembelajaran tematik terpadu merupakan pendekatan pembelajaran yang terdiri dari beberapa mata pelajaran dalam satu tema untuk memberikan pengalaman yang bermakna bagi peserta didik. Hal tersebut sesuai dengan pendapat menurut Desyandri \& Vernanda (dalam Putra \& Desyandri,2020) menyatakan bahwa pembelajaran tematik terpadu adalah suatu pembelajaran yang menggunakan tema dengan mengaitkan beberapa muatan mata pelajaran sehingga memberikan pembelajaran yang bermakna kepada peserta didik. Dalam pembelajaran guru diharapkan menggunakan model pembelajaran yang sesuai dengan kebutuhan di kelas. Sehingga dapat meningkatkan hasil belajar peserta didik. Hasil belajar dijadikan sebagai tolak ukur terhadap keberhasilan peserta didik dalam penguasaan materi dalam setiap pembelajaran.

Berdasarkan observasi yang telah dilaksanakan di SD Negeri 2 Tlahab Lor di kelas $\mathrm{V}$ dengan adanya permasalahan peserta didik masih kurang percaya diri dalam menyampaikan hasil diskusi, sebagian peserta didik masih kurang aktif. Selanjutnya peserta didik ketika melakukan diskusi masih terlihat individual dan kurang terlihatnya kerja sama antar peserta didik tersebut. Dapat dilihat pada saat melakukan kegiatan diskusi, didalam kelompok tidak terlihat bahwa peserta didik benar-benar melakukan diskusi, di dalam kelompok hanya beberapa orang saja yang melakukan diskusi dan mengerjakan apa yang di minta oleh guru sehingga tidak terlihat kerja sama di dalam kegiatan tersebut.

Berdasarkan identifikasi masalah diatas, apakah model pembelajaran problem based learning dapat digunakan untuk meningkatkan hasil belajar peserta didik?.Untuk mengoptimalkan pembelajaran tersebut, guru harus menggunakan model pembelajaran yang tepat dalam pengimplementasian pembelajaran tematik terpadu, sehingga masalah tersebut dapat teratasi dengan baik. Model pembelajaran yang tepat untuk permasalahan ini adalah model problem based learning merupakan model pembelajaran yang menuntut peserta didik untuk berfikir kritis dalam memecahkan suatu masalah, aktif bekerja sama dalam kelompok, peserta didik bebas mengemukakan idenya dengan teman dan mengaitkan pengalaman kehidupan nyata peserta didik. Menurut Bloom yang dikutip oleh Agus Suprijono (2013:6) mengatakan bahwa hasil belajar mencakup kemampuan kognitif, afektif, dan psikomotor. Dengan demikian peneliti melaksanakan penelitian tindakan kelas dengan Model Pembelajaran Problem Based Learning (PBL) diharapkan mampu meningkatkan hasil belajar siswa kelas V SD Negeri 2 Tlahab Lor.

\section{METODE}

Jenis penelitian yang digunakan merupakan Penelitian Tindakan Kelas (PTK). PTK mempunyai tujuan untuk memperbaiki mutu praktik pembelajaran dan perilaku siswa di kelas. Subyek pada penelitian ini adalah peserta didik kelas V di SD Negeri 2 Tlahab Lor dengan jumlah 26 siswa. Penelitian dilakukan minimal 2 siklus. Model penelitian dari Kemmis dan Taggart dalam Suharsimi Arikunto (2010 : 132) dapat dilakukan melalui 4 tahap yaitu perencanaan (planning), pelaksanaan tindakan (action), pengamatan (observing), dan refleksi (refleting). Teknik pengumpulan data di dalam penelitian berupa tes, lembar observasi dan dokumentasi. Tes berupa tes objektif yaitu soal tes.

Hasil dari uji validitas Jurnal Riset Teknologi dan Inovasi Pendidikan Volume 1 Nomor 2 (Juli) 2018, Hal. 99-108 101 dan reliabilitas soal pada Siklus I dari 40 soal. Reliabilitas pada soal siklus I sebesar 0,83 dalam kriteria reliabel. Hasil uji validitas dan reliabilitas pada Siklus II terdiri dari 40 soal, yang terdapat 21 soal valid. Dari 21 soal yang valid, digunakan 20 soal untuk instrument penelitain Siklus II oleh peneliti. Sedangkan reliabilitas soal Siklus II sebesar 0,81 dalam kriteria reliabel. Sedangakan 
observasi pada penelitian ini dilakukan untuk mengamati tindakan guru dalam menerapkan model pembelajaran Problem Based Learning (PBL) dan respon siswa dalam menerima pembelajaran. Teknis analisis data dalam penelitian ini menggunakan data kuantitatif yang dianalisis dengan menggunakan tehnik analisis deskriptif untuk menentukan rata-rata terlebih dahulu. Hasil belajar siswa yang telah didapat dibandingkan dengan KKM. Selain dengan menggunkan data kuantitatif juga menggunakan data kualitatif. Data kualitatif dianalisis dengan tehnik analisis deskriptif kualitatif. Selain dengan menggunkan data kuantitatif juga menggunkan data kualitatif. Data kualitatif dianalisis dengan tehnik analisis deskriptif kualitatif.

\section{HASIL DAN PEMBAHASAN}

Hasil belajar atau hasil pngetahuan siswa dalam penelitian ini mengalami peningkatan. Pada siklus I rata-rata nilai siswa adalah 69,32 dengan jumlah siswa tuntas sebanyak 13 dan persentase ketuntasan sebesar $52 \%$. Kemudian pada siklus II meningkat ditunjukkan oleh nilai rata-rata siswa menjadi 78,66 dengan jumlah siswa tuntas sebanyak 16 dan persentase ketuntasan sebesar $64 \%$. Sementara itu, pada siklus III mengalami peningkatan kembali ditunjukkan dengan nilai rata-rata siswa menjadi 79 dengan jumlah siswa tuntas sebanyak 22 dan persentase ketuntasan sebesar $88 \%$.

Adapun Menurut Sri Giarti (2014:3) Model Pembelajaran Problem Based Learning (PBL)adalah suatu model pembelajaran dengan masalah autentik yang diharapkan siswa dapat menyusun, mengebangkan keterampilan yang lebih tinggi dan inquiry, dengan adanya pendekatan siswa diarahkan untuk lebih meningkatkan kepercayaan diri dan lebih mandiri. Model Pembelajaran Problem Based Learning (PBL) merupakan sebuah model pembelajaran yang dimana siswa pada suatu masalah nyata dalam kehidupan sehari-hari untuk memulai pembelajaran serta memecahkan masalahnya dan merupakan salah satu pembelajaran inovatif yang dapat memberikan kondisi siswa aktif belajar dan diharapkan dapat menciptakan pengalaman belajar bagi siswa. Guru menjadi motivator, fasilitator serta pembimbing siswa dalam menyelesaikan masalah.

Pembelajaran tematik adalah pembelajaran yang tersusun secara terpadu. Menurut Rusman (2012:254) pembelajaran tematik adalah sebuah model pembelajaran terpadu (integrated instruction) dengan sistem pembelajaran yang memiliki kemungkinan siswa belajar secara individu maupun kelompok, siswa aktif mencari dan menemukan konsep serta prinsip keilmuan secara holistic, bermakna dan autentik. Menurut Anintah (2008:118) pembelajaran tematik dinyatakan sebagai suatu kegiatan belajar yang melibatkan beberapa muatan pelajaran yang berkaitan dengan tema yang dirancang dalam suatu ide. Belajar tematik dengan menggunakan tema sentral dalam kegiatan belajar yang berlangsung. Ciri-ciri pembelajaran tematik terpadu menurut Mawardi (2014:4) yaitu: a) siswa menjadi pusat, b) secara langsung memberikan pengalaman kepada siswa, c) dalam kegiatan pembelajaran menyatu menjadi satu pemahaman, d) satu konsep pembelajaran terdiri dari berbagai muatan pembelajaran, e) bersifat luwes, f) minat dan kebutuhan siswa berasal dari perkembangan hasil belajar.

Hasil belajar menurut Mawardi \& Supriyati (2015:6) adalah keterampilan dan kecakapan yang dimiliki oleh siswa setelah mengalami proses belajar.Pelaksanaan tindakan pada penelitan ini dilaksanakan dalam 2 siklus. Pelaksanaan tindakan dari siklus I ke siklus II mengalami peningkatan. Dengan adannya perbaikan pada siklus II, hasil belajar tematik terpadu siswa meningkat sehingga dapat mencapai keberhasilan pembelajaran. Berikut ini tabel yang menunjukkan peningkatan hasil belajar siswa pada setiap siklus. 
SHEs: Conference Series 3 (4) (2020) 257- 261

Tabel. Persentase Hasil Belajar

\begin{tabular}{cccc}
\hline No & Pra & Siklus I & Siklus II \\
\hline A & $43,07 \%$ & $55 \%$ & $63,46 \%$ \\
B & $35,19 \%$ & $48,85 \%$ & $59,62 \%$ \\
C & $39,23 \%$ & $48,85 \%$ & $65,77 \%$ \\
D & $36,54 \%$ & $55 \%$ & $58,07 \%$ \\
E & $38,27 \%$ & $47,69 \%$ & $63,57 \%$ \\
\hline
\end{tabular}

Keterangan :

Indikator A : Muatan Pelajaran PPKn

Indikator B : Muatan Pelajaran Bahasa Indonesia

Indikator C : Muatan Pelajaran IPA

Indikator D : Muatan Pelajaran IPS

Indikator E : Muatan Pelajaran SBdP

Berdasarkan tabel diatas, menunjukkan bahwa persentase hasil belajar yang tertinggi pada pra tindakan adalah indikator A (Muatan Pelajaram PPKn). Siklus I persentase tertinggi terdapat pada indikator A (Muatan Pelajaran PPKn) dan D (Muatan Pelajaran IPS). Selanjutnya untuk siklus II, persentase tertinggi terdapat pada indikator C (Muatan Pelajaran IPA). Berikut ini akan diuraikan setiap indikator yang meningkat pada setiap siklus.

Persentase peningkatan indikator dari pra tindakan ke siklus I adalah $9,42 \%$ dan siklus I ke siklus II adalah 15,58\%. Berdasarkan hasil persentase tersebut dapat disimpulkan bahwa model pembelajaran Problem Based Learning berhasil digunakan. Berdasarkan perhitungan setiap indikator, persentase rata-rata hasil belajar pada pra tindakan sebesar $38,46 \%$ dengan kualifikasi sangat kurang. Siklus I sebesar $51,08 \%$ dengan kualifikasi kurang. Siklus II sebesar 62,04\% dengan kualifikasi cukup. Persentase rata-rata hasil belajar siswa dari pra tindakan ke siklus I mengalami peningkatan sebesar $12,62 \%$. Kemudian dari siklus I ke siklus II sebesar 10,96\%.

Hasil penelitian menunjukkan bahwa hasil belajar dari pra tindakan diperoleh persentase ketuntasan 23,08\% atau 6 siswa yang memenuhi KKM dengan nilai ratarata 47,16. Siklus I hasil belajar diperoleh persentase ketuntasan $34.62 \%$ atau 9 siswa yang memenuhi KKM dengan nilai rata-rata 55,26. Siklus II hasil belajar diperoleh persentase ketuntasan $57,69 \%$ atau 15 siswa yang memenuhi KKM dengan nilai ratarata 66,88 .

\section{SIMPULAN}

Berdasarkan hasil penelitian dan pembahasan, dapat diambil simpulan sebagai berikut 1) Proses pembelajaran sudah sesuai dengan aturan pada Problem Based Learning. Setiap siklus melakukan proses pembelajaran dengan peneliti membagi kelas menjadi 6 kelompok. Setiap kelompok terdiri dari 4 sampai 5 orang. Setelah itu, peneliti memberikan LKPD yang berisi soal uraian kepada setiap kelompok. Pada tahap ini, siswa berdiskusi bersama untuk memikirkan jawaban dan menyakinkan setiap anggotanya atas soal yang diberikan oleh peneliti. Setelah selesai berdiskusi, peneliti memanggil salah satu peserta didik untuk mewakili kelompoknya dan mempresentasikan hasil diskusi. 2) Model pembelajaran Problem Based Learning dapat meningkatkan hasil belajar siswa dari pra tindakan sebesar $38,46 \%$. Siklus I sebesar $51,08 \%$ dan siklus II sebesar 62,04\%. 3) Model pembelajaran Problem Based Learning dapat meningkatkan hasil belajar siswa dari pra tindakan persentase nilai rata-rata sebesar $23,08 \%$. Siklus I persentase nilai rata-rata sebesar $34,62 \%$ dan siklus II sebesar 57,69. berdasarkan analisis dan simpulan yang sudah dipaparkan oleh peneiti, maka peneliti memberikan saran. Untuk meningkatkan hasil belajar peserta didik dapat digunakan model pembelajaran Problem Based Learning (PBL). 
DAFTAR PUSTAKA

Anitah,S. (2008).Strategi Pembelajaran di SD. Jakarta: Universitas Terbuka

Arikunto, Suharsimi (2010). Prosedur Penelitian Suatu Pendekatan Praktik.Jakarta:Rineka Cipta.

Ashari Nur Wahidin, dan Salwah. (2017). Problem Based Learning (PBL) dalam Meningkatkan kecakapan Pembuktian matematis mahasiswa Calon Guru. Jurnal Matematika dan Pendidikan Matematika, 2 (2) 3.

Desyandri, D., \& Vernanda. (2017). Pengembangan Bahan Ajar Tematik Terpadu Di Kelas V Sekolah Dasar Menggunakan Identifikasi Masalah. Seminar Nasional HDPGSDI Wilayah 4 (pp. 163-174).

Giarti, Sri. (2014). Implementasi Keterampilan Proses Pemecahan Masalah dan Hasil Belajar Matematika menggunakan Model PBL terintedrasi Penilian Autentik Pada Siswa Kelas VI SD N 2 Bengle Wonosegoro. Scholaria, 4 (3) 3.

Hamdani. (2011).Strategi Belajar Mengajar.Bandung:Pustaka Setia.

Machali, Imam. (2014). Kebijakan Kurikulum 2013 daam Menyongsong Indonesia Emas Tahun 2045. Jurnal Pendidikan Islam, 3 (1) 2

Mawardi dan Supriyati. (2015). Keefektifan Model Pembelajaran Kooperatif The Group Investigation (GI) Dan Inquiry Dalam Pembelajaran IPS Kelas V SD. Scholaria, 5 (2) 6

Mawardi. (2014). Pemberlakuan Kurikulum SD/MI Tahun 2013 dan Implikasinya Terhadap Upaya Memperbaiki Proses Pembelajaran Melalui PTK. Scholaria, 4 (3) 4

Nurgiyantoro, Burhan. (2012). Penilaian Pembelajaran Bahasa Berbasis Kompetensi.Yogyakarta:BPFE Yogyakarta.

Putra, B. A., \& Desyandri, D. (2020). Penerapan Model Problem Based Learning untuk Meningkatkan Proses Pembelajaran Tematik Terpadu Kelas IV Sekolah Dasar.Pembelajaran Inovasi, Jurnal IImiah, 8. http://ejournal.unp.ac.id/students/index.php/pgsd/article/view/9057 